\title{
RELATIONSHIP OF SERUM PROCALCITONIN LEVELS AND C-REAC- TIVE PROTEIN LEVELS IN NEWBORNS WITH SEPSIS IN DIFFERENT TYPES OF RESPIRATORY SUPPORT IN INTENSIVE CARE UNIT
}

Aspazija Sofijanova ${ }^{1}$, Sonja Bojadzieva ${ }^{1}$, Silvana Naunova- Timovska ${ }^{1}$, Hristina Mangjukovska ${ }^{1}$, Elizabeta Shuperliska², Olivera Jordanova²

\section{University Clinic for children's diseases; Ss. Cyril and Methodius University in Skopje, Faculty of Medicine,}

Skopje, Republic of North Macedonia

University Clinic for children's diseases, Skopje, Republic of North Macedonia

Citation: Sofijanova A, Bojadzieva B, NaunovaTimovska S, Mangjukovska H, Shuperliska E, Jordanova O. Relationship of serum procalcitonin levels and c-reactive protein levels in newborns with sepsis in different types of respiratory support in intensive care unit. Arch Pub Health 2021; 13 (1).

doi.org/10.3889/aph.2021.5995

Key words: procalcitonin, newborns, respiratory distress syndrome.

*Correspondence: Aspazija Sofijanova, University Clinic for children's diseases - Skopje, Republic o North Macedonia. E-mail: aspaziculi@yahoo.com Received: 12-Fev-2021; Revised: : 20-Mar-2021; Accepted: 28-Mar-2021; Published: 2-Apr-2021 Copyright: ${ }^{-2021}$. Aspazija Sofijanova, Sonja Bojadzieva, Silvana Naunova- Timovska, Hristina Mangjukovska, Elizabeta Shuperliska, Olivera Jordanova. This is an open-access article distributed under the terms of the Creative Commons Attribution License, which permits unrestricted use, distrbution, and reproduction in any medium, provided the original author(s) and source are credited.

Competing Interests: The author have declared that no competing interests

\begin{abstract}
Sepsis in newborns with RDSy and asphyxia is essential; it is a life-threatening condition and still represents an important cause of mortality and morbidity. The aim of this study was to evaluate the predictive values of procalcitonin (PCT) as an early diagnostic and prognostic biochemical marker for sepsis in newborns with RDS and asphyxia. Material and methods: The study was designed as prospective and we examined 110 newborns with proven sepsis admitted in the Intensive Care Unit at the University Clinic of Pediatrics - Skopje in the period between December 2018 and January 2021. Procalcitonin levels were measured by using the immunoassay system Vidas based on the ELFA principles. The newborns with proven sepsis were divided into two groups. The first group comprised 55 newborns with RDS and proven sepsis and the second group included 55 newborns with asphyxia and proven sepsis. The statistical analysis confirmed significantly different values of PCT in the analyzed time period in first group of newborns with RDS and proven sepsis, $p<0.001$. The highest average values (40.37 \pm 53.79$)$ were measured on admission with a high level of peak compared to the second group of newborns with asphyxia and proven sepsis. The statistical analysis confirmed significantly different values of PCT in the analyzed time period in the first group of newborns with RDS and proven sepsis with mechanical ventilation (MV) and bubble continuous positive airway pressure (BCPAP) compared to the second group of newborns with asphyxia and proven sepsis, $\mathrm{p}<0.001$. PCT is a promising sepsis marker in newborns with RDSy, capable of complementing clinical signs and routine laboratory parameters suggestive of severe infection at the time of ICU admission.
\end{abstract}

Клинички истражувања

ОДНОСОТ ПОМЕГ์У НИВОТО НА СЕРУМСКИОТ ПРОКАЛЦИТОНИН
ИЦ-РЕАКТИВЕН ПРОТЕИН КАЈ НОВОРОДЕНЧИНА СО СЕПСА
ПРИ РАЗЛИЧНИ ВИДОВИ НА РЕСПИРАТОРНА ПОДДРШКА ВО
ЕДИНИЦАТА ЗА ИНТЕНЗИВНА НЕГА И ТЕРАПИЈА

Аспазија Софијанова ${ }^{1}$, Соња Бојаџиева $^{1}$, Силвана Наунова-Тимовска ${ }^{1}$, Христина Манџуковска, Елизабета Шуперлиска², Оливера Јорданова²

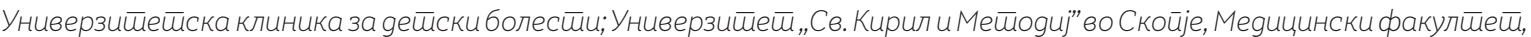
Рейублика Северна Макеgонија

Универзитеиейска клиника за вейски болестии, Скойје, Рейублика Северна Макеgонија

Цитирање: Софијанова А, Бојаџиева С, Наунова-Тимовска С, Манџуковска X, Шуперлиска Е, Јорданова О. Односот помеѓ нивото на серумскиот прокалцитонин и ц-реактивен протеин кај новороденчиња со сепса при различни ви дови на респираторна поддршка во единицата за интензивна нега и терапија. Арх J Здравје 2021:13(1)

doi.org/10.3889/aph.2021.5995

Клучни зборови: прокалцитонин, новороденчиња, респираторен дистрес синдром

*Кореспонденција: Аспазија Софијанова, Универзитетска клиника за детски болести Скопје, Република Северна Македонија, E-mail: aspaziculi@yahoo.com

Примено: 12-фев-2021; Ревидирано: 20-мар-2021; Прифатено: 28-мар-2021; Објавено: 2-апр-2021

Печатарски права: ${ }^{2} 2021$ Аспазија Софијанова, Соња Бојаџиева, Силвана Наунова-Тимовска, Христина Манџуковска, Елизабета Шуперлиска, Оливера орданова. Оваа статија е со отворен пристап дистрибуирана под условите на нелокализирана лиценца, која овозможува неограничена употреба, дистрибуција и репродукциј на било којмедиум доколку се цитираат оригиналниот(ите) автор(и) и изворот.

Конкурентски интереси: Авторот изјавува дека нема конкурентски интереси.

\section{Извадок}

Сепсата кај новороденчиња со респираторен дистрес синдром (РДС) и асфиксија е животозагрозувачка состојба и сѐ уште претставува важна причина за морталитет и морбидитет. Целта на оваа студија беше да се проценат предвидувачките вредности на прокалцитонинот (ПЦТ) како ран дијагностички и прогностички биохемиски маркер за сепса кај новороденчиња со РДС и асфиксија. Студијата беше дизајнирана како проспективна и испитавме 110 новороденчиња со докажана сепса, хоспитализирани во Единицата за интензивна нега и терапија (ЕИНТ), при Универзитетската клиника за детски болести - Скопје, во периодот од декември 2018 до јануари 2021 година. Нивото на прокалцитонин беше мерено со користење на иму ноанализирачкиот систем Видас базиран на ЕЛФА методот. Новороденчињата со докажана сепса беа поделени во две групи. Во првата група беа анализирани 55 новороденчиња со РДС и докажана сепса, а во втората група 55 новороденчиња со асфиксија и докажана сепса. Статистичката анализа потврди значително различни вредности на ПЦТ во анализираниот период во првата група новороденчиња со РДС и докажана сепса, p<0,001. Највисоките просечни вредности $(40,37 \pm 53,79)$ беа измерени за време на приемот со висок пик во споредба со втората група новороденчиња со асфиксија и докажана сепса. Статистичката анализа потврди сигнификантно различни вредности на ПЦТ во анализираниот временски период кај прва та група новороденчиња со РДС и докажана сепса со механичка вентилација (MB) и bubble континуиран позитивен притисок на дишните патишта (БЦПАП), споредено со втората група новороденчиња со асфиксија и докажана сепса, $p<0,001$. ПЦТ е ветувачки маркер за сепса кај новороденчиња со РДС, кој ја надополнува клиничката презентација и рутинските лабораториски параметри кои укажуваат на тешка инфекција за време на хоспитализацијата во ЕИНТ. 


\section{Introduction}

Sepsis is a leading cause of mortality and morbidity in newborns. The incidence of sepsis is higher in newborns with respiratory distress syndrome (RDSy), asphyxia, in infants with low gestational week and low-birth weight ${ }^{1,2}$. New advances in biochemical monitoring are important in assessing the risk of developing septic shock, severe sepsis, or sepsis ${ }^{3,4}$. However, bacterial inflammation in the postnatal period is still a leading factor in morbidity and mortality ${ }^{5}$. Sepsis in newborns is present with features of clinical manifestations of infection and inflammation while severe sepsis in septic newborns is the development of hypoperfusion with multiple organic dysfunction. Multiorgan failure with hypoperfusion and persistent hypotension is found in septic shock ${ }^{6,7}$. Sepsis is a common complication in newborns with RDS and asphyxia, because of intensive procedures during their therapy. Asphyxia is a disturbed change of respiratory gases in the placenta of the fetus during childbirth, or in the lungs of the newborn after childbirth that causes progressive hypoxia and hypercapnia. This can lead to systemic and neurological sequelae. Early consequences are observed in the first minutes of life due to the effects of hypoxia and acidemia on: the brain (primary apnea and difficulty in establishing the rhythm of breathing), heart (bradycardia), lungs (absence of vasodilation of the pulmonary arteries and retention of the fetal blood flow pattern), other organ systems that may be affected by asphyxia in the first hours and days - such as the kidneys and intestines. Late consequences of perinatal asphyxia in surviving infants may be: permanent brain damage - cerebral palsy, mental retardation, epilepsy, while other organ systems will not normally be permanently damaged ${ }^{8}$. RDSy is a disease of the hyaline membrane due to a lack of surfactant in the lungs of premature newborns. There are risk factors that lead to an increased incidence of RDSy such as male sex, white race, caesarean section, prematurity, multiple short pregnancies and preterm newborns from mothers with diabetes ${ }^{9,10}$. Radiological studies show diffuse atelectasis which is described as ground-glass appearance with visible air bronchograms and low lung expansion $^{11,12}$. The therapy for RDSy and asphyxia consists of supportive measures and initial placement of the newborn on nasal CPAP with a PEEP of 3-8 $\mathrm{cm} \mathrm{H}_{2} \mathrm{O}$. If respiratory failure persists, endotracheal intubation and mechanical ventilation are performed. Surfactant is administered in RDSy endotracheally within two hours of delivery ${ }^{13,14}$. The aims of neonatal respiratory support is to create adequate gas exchange while minimizing the risk of lung injury. There are different forms of neonatal respiratory support: supplemental oxygen, continuous positive airway pressure (CPAP), noninvasive positive pressure ventilation (NIPPV) and mechanical ventilation (MV). In newborns who are unable to achieve oxygenation by any of these methods, techniques of high frequency oscillatory ventilation, extracorporeal membrane oxygenation, nitric oxide therapy or a combination are applied ${ }^{15}$. Mechanical ventilation is one of the most common therapies in the neonatal intensive care unit and is associated with increased morbidity and mortality. The indications of mechanical ventilation in newborns are respiratory distress 
syndrome, asphyxia, meconium aspiration, congenital pneumonia, lung hemorrhage, septic shock. Bubble CPAP is a non-invasive ventilation strategy for newborns. This method reduces the complications of invasive ventilation ${ }^{16}$. Also, any intensive respiratory support procedure performed in newborns has a higher risk of developing sepsis ${ }^{17}$.

Biomarkers can play an important role in providing a timely diagnosis of sepsis and the decision for making the initial management. Rapid elevation in the concentration of procalcitonin (PCT) is a promising indicator of sepsis in newly admitted critically ill newborns capable of complementing clinical signs and routine laboratory parameters, hence, makes it an ideal biochemistry marker for bacterial infection18.

\section{Material and methods}

The study was designed as prospective and we examined 110 newborns with proven sepsis admitted in the Intensive Care Unit at the University Clinic for Pediatrics - Skopje in the period between December 2018 and January 2021.

Early signs of cepsis diagnosis in newborns are frequently nonspecific and subtle and do not distinguish among organisms. Particularly common early signs include two or more of the following criteria: apnea, bradycardia, hypothermia, hyperthermia, vomiting, seizures, jaundice, especially occurring within the first 24 hours of life with a higher direct bilirubin concentration, diarrhea, abdominal distention. Diagnosis is confirmed by isolation of a pathogen in blood culture and level of PCT $>0.5 \mathrm{ng} / \mathrm{ml}$. The laboratory biomarkers were done in the Clinical Laboratory at the University Clinic for Pediatrics - Skopje. Firstly, samples for blood culture and PCT were taken on admission, and afterwards on 3-5 day and on 6-14 day. Procalcitonin was determined by immunoassay: patented ELFA (Enzymelinked fluorescent assay) technology, automated Vidas Biomerieux immunoassay (ng/ml). CRP levels were determined by using the immunoturbidimetric method Architect c4000 Abbott $(\mathrm{mg} / \mathrm{L})$. Blood culture media were incubated at $37^{\circ} \mathrm{C}$ for 5 days in BactAlert 3D 360. Positive blood cultures were isolated with the new multiplex polymerase chain reaction -based rapid diagnostic test (BioFire FilmAray Blood Culture Identification).

Data were analyzed with the Statistica program 7.1 for Windows and SPSS Statistics 23.0, to compare the means of the variables, and one-way ANOVA test. For all analyses, p value $<0.05$ was taken as statistically significant.

\section{Results}

In our study we examined 110 (M:F=68:42) newborns with proven sepsis admitted to the Intensive Care Unit (ICU) at the University Clinic for Pediatrics - Skopje in the period between December 2018 and January 2021.

The newborns with proven sepsis were divided into two groups. The first group comprised 55 newborns with RDS and proven sepsis and the second group included 55 newborns with asphyxia and proven sepsis. Table 1 shows the distribution of the first and second group depending on birth weight. 
Table 1 Distribution of first and second group depending on birth weight

\begin{tabular}{|c|c|c|c|c|c|}
\hline Birth weight & \multicolumn{2}{|c|}{$\begin{array}{c}\text { Sepsis and RDS } \\
\text { group }\end{array}$} & \multicolumn{2}{|c|}{$\begin{array}{c}\text { Sepsis and Asphyxia } \\
\text { group }\end{array}$} & \multirow{2}{*}{ Tested difference } \\
\cline { 1 - 5 }$<1000 \mathrm{~g}$ & 6 & $10.90 \%$ & 5 & $9.10 \%$ & \\
\cline { 1 - 5 } $1000-1500 \mathrm{~g}$ & 9 & $16.40 \%$ & 12 & $21.80 \%$ & \multirow{2}{*}{$\begin{array}{c}\text { Fisher exact } 12.996 \\
\mathrm{df}=16 \mathrm{p}=0.642\end{array}$} \\
\cline { 1 - 4 } $1500-2500 \mathrm{~g}$ & 11 & $20.00 \%$ & 9 & $16.40 \%$ & \\
\cline { 1 - 4 } $2500-3500 \mathrm{~g}$ & 24 & $43.60 \%$ & 23 & $41.80 \%$ & \\
\cline { 1 - 4 }$>3500 \mathrm{~g}$ & 5 & $9.10 \%$ & 6 & $10.90 \%$ & \\
\hline
\end{tabular}

There was no statistically significant difference in the average birth weight between the two groups $(\mathrm{p}<0.01)$.

Table 2 Distribution of first and second group depending on gestational age

\begin{tabular}{|c|c|c|c|c|c|}
\hline Gestational age & \multicolumn{2}{|c|}{ First group } & \multicolumn{2}{|c|}{ Second group } & Tested difference \\
\hline$<37$ weeks & 31 & $56.40 \%$ & 30 & $54.50 \%$ & $\begin{array}{ll}\text { Chi-square: } & 1,304 \\
d f=1 & \end{array}$ \\
\hline >37 weeks & 24 & $43.60 \%$ & 25 & $45.50 \%$ & $p=0.254$ \\
\hline
\end{tabular}

Table 3 shows the distribution of the first and second group depending on type of respiratory support. There was no statistically significant difference between invasive and non-invasive respiratory support in the two groups $(\mathrm{p}<0.01)$.

Table 3 Distribution of first and second group depending on types of respiratory support

\begin{tabular}{|c|c|c|c|c|ll|}
\hline $\begin{array}{c}\text { Types on respiratory } \\
\text { support }\end{array}$ & \multicolumn{2}{|c|}{ First group } & \multicolumn{2}{c|}{ Second group } & \multicolumn{2}{|c|}{ Tested difference } \\
\hline MV & 26 & $45.60 \%$ & 32 & $56.10 \%$ & Chi-square: & 4.105 \\
\hline B CPAP & 17 & $29.80 \%$ & 13 & $23.60 \%$ & $\mathrm{df}=2$ & \\
\hline OXYGEN MASK & 14 & $24.60 \%$ & 10 & $18.20 \%$ & $\mathrm{p}=0.128$ & $\mathrm{~ns}$ \\
\hline
\end{tabular}

The statistical analysis confirmed significantly different values of PCT in the analyzed time period in the first group of newborns with RDS and proven sepsis, $\mathrm{p}<0.001$ (Table 4$)$. The highest average values $(40.37 \pm 53.79)$ were measured on admission with a high level of peak compared to the second group of newborns with asphyxia and proven sepsis. After the second measure- 
ment on 3-5 days, the average values of PCT in the first group of newborns with RDS and proven sepsis slowly decreased (37.06 \pm 46.19$)$ so that after the third measurement on day 6-14 in the first group of newborns with RDS and proven sepsis, they slowly began to normalize $(9.78 \pm 15.58)$.

Table 4 Distribution of average PCT value in newborns with RDS and proven sepsis over time

\begin{tabular}{|c|c|c|c|c|c|c|c|}
\hline \multirow{2}{*}{$\begin{array}{l}\text { Average } \\
\text { PCT value }\end{array}$} & \multicolumn{3}{|c|}{ First group $N=55$} & \multicolumn{3}{|c|}{ Second group N=55 } & Tested difference \\
\hline & mean*sd & Min-max & median & mean*sd & $\begin{array}{l}\text { min-m } \\
\text { dian }\end{array}$ & me- & \multirow{4}{*}{$\begin{array}{c}\text { Friedman ANOVA } \\
\text { Chi.Sqr }=137,591 \\
p=<0.001\end{array}$} \\
\hline $0-24 h$ & $\begin{array}{c}40.37^{\star} \\
53.79\end{array}$ & $\begin{array}{c}0.05- \\
198.20\end{array}$ & 17,68 & $\begin{array}{c}12.42^{*} \\
30.29\end{array}$ & $\begin{array}{c}0.17- \\
200\end{array}$ & 4,34 & \\
\hline 3-5 days & $\begin{array}{c}37.05^{\star} \\
46.19 \\
\end{array}$ & $\begin{array}{c}1.85- \\
163.36 \\
\end{array}$ & 16,73 & $\begin{array}{l}9.40^{*} \\
29.68\end{array}$ & $\begin{array}{c}0.17- \\
218 \\
\end{array}$ & 3,15 & \\
\hline 6-14 days & $\begin{array}{l}9.78^{*} \\
15.58\end{array}$ & $0.05-88.00$ & 4,55 & $\begin{array}{l}2.88- \\
4.98\end{array}$ & $\begin{array}{l}0.05- \\
22.00\end{array}$ & 1,5 & \\
\hline
\end{tabular}

There was a statistically significant difference in the average PCT between the two groups over time $(\mathrm{p}<0.05)$.

The statistical analysis confirmed significantly different values of CRP in the analyzed time period in the first group of newborns with RDS and proven sepsis, $\mathrm{p}<0.001$ (Table 5). At the first measurement, the average values of CRP in the first group of newborns with RDS and proven sepsis slowly increased (25.40 \pm 44.37$)$.
The highest average values in the first group of newborns with RDS and proven sepsis were measured $(46.17 \pm 60.81)$ after the second measurement on day 3-5, with a high level of peak compared with the second group of newborns with asphyxia and proven sepsis. At the third measurement in the first group of newborns with positive blood culture on day 6-14, the average values of CRP slowly decreased (21.53 \pm 29.59$)$.

Table 4 Distribution of average PCT value in newborns with RDS and proven sepsis over time

\begin{tabular}{|c|c|c|c|c|c|c|c|}
\hline \multirow{2}{*}{$\begin{array}{l}\text { Average } \\
\text { PCT value }\end{array}$} & \multicolumn{3}{|c|}{ First group $N=55$} & \multicolumn{3}{|c|}{ Second group N=55 } & Tested difference \\
\hline & mean*sd & Min-max & median & mean*sd & $\begin{array}{l}\text { min-m } \\
\text { dian }\end{array}$ & me- & \multirow{4}{*}{$\begin{array}{c}\text { Friedman ANOVA } \\
\text { Chi.Sqr }=48,501 \\
p=<0.001\end{array}$} \\
\hline $0-24 h$ & $\begin{array}{l}12.81^{*} \\
35.59 \\
\end{array}$ & $\begin{array}{c}0.00- \\
180.00\end{array}$ & 1.5 & $\begin{array}{l}25.40^{*} \\
44.37\end{array}$ & $\begin{array}{c}0.00- \\
194 \\
\end{array}$ & 4,7 & \\
\hline 3-5 days & $\begin{array}{l}28.94- \\
46.85\end{array}$ & $\begin{array}{c}0.20- \\
212.00\end{array}$ & 11 & $\begin{array}{c}46.17^{\star} \\
60.81\end{array}$ & $\begin{array}{c}0.30- \\
266.60\end{array}$ & 13 & \\
\hline 6-14 days & $\begin{array}{l}17.37^{\star} \\
33.34\end{array}$ & $\begin{array}{c}0.20- \\
160.00\end{array}$ & 5 & $\begin{array}{l}21.53^{\star} \\
29.59\end{array}$ & $\begin{array}{c}0.20- \\
115\end{array}$ & 8,2 & \\
\hline
\end{tabular}

There was a statistically significant difference in average PCT between the two groups over time $(\mathrm{p}<0.05)$.
The statistical analysis confirmed significantly different values of PCT in the analyzed time period in the first group of newborns with RDS 
and proven sepsis with mechanical ventilation (MV) and bubble continuous positive airway pressure (BCPAP) compared to the second group of newborns with asphyxia and proven sepsis $\mathrm{p}<0.001$.

The statistical analysis confirmed significantly different values of CRP in the analyzed time period in the second group of newborns with asphyxia and proven sepsis with MV and BCPAP, $p<0.001$, compared to the first group of newborns with RDS and proven sepsis.

\section{Discussion}

Sepsis is an important cause of mortality and morbidity in newborns. It is a systemic response to infection by microbial organisms and it is a lifethreatening condition. For pediatricians the early identification of infections is a challenge. The etiology of sepsis in this situation is not always clear ${ }^{20,21}$. The highest incidence occurrs among newborns with asphyxia, respiratory distress syndrome (RDSy), newborns with low gestational week and low birth weight. Sepsis in newborns with asphyxia and RDSy is essential life-threatening condition and still represents an important cause of mortality and morbidity ${ }^{22,23}$. Sepsis is a common complication in newborns with RDS and asphyxia, because of the intensive procedures during their therapy. Also, asphyxia and RDSy are a common cause of hospitalization in the ICU. It is the leading cause of death in newborns ${ }^{24,25}$. Newborns with asphyxia and RDSy have a higher risk of developing a septic condition with severe clinical presentation, longer duration of mechanical respiratory support, and worse outcome. Risk factors for sepsis in the postnatal period include: male gender, birth weight $<1000$ grams, hypogammaglobulinemia, central venous catheters, intravenous alimentation and prolonged duration of mechanical ventilation ${ }^{26,27}$. Also, any intensive respiratory support procedure performed on newborns poses a higher risk of developing sepsis. Therefore, early recognition, early diagnosis and timely treatment to improve outcome are important issues in septic newborns with these two conditions. Early biomarkers to diagnose sepsis in ICU are widely used in clinical practice and they are useful in monitoring the infectious process, and can reduce the risk of death in newborns with asphyxia and RDSy. Ideal biomarkers for sepsis should have high sensitivity and specificity with early phase elevation, low cost and quick result ${ }^{28,29}$. The diagnostic performance of PCT in numerous studies from the literature has suggested PCT to be a useful marker in the diagnosis of sepsis in newborns with RDSy ${ }^{30}$.

In our study we examined PCT and CRP values in newborns with asphyxia and RDSy with proven sepsis. The statistical analysis confirmed significantly different values of PCT in the analyzed time period in the first group of newborns with RDS and proven sepsis, $\mathrm{p}<0.001$. The highest average values $(40.37 \pm 53.79)$ were measured on admission with a high level of peak compared to the second group of newborns with asphyxia and proven sepsis. The statistical analysis confirmed significantly different values of CRP in the analyzed time period in the first group of newborns with RDS and proven sepsis, $\mathrm{p}<0.001$. At the first measurement, the average values of CRP in the first group of newborns with RDS and proven 
sepsis slowly increased (25.40 \pm 44.37$)$. The highest average values in the first group of newborns with RDS and proven sepsis were measured (46.17 \pm 60.81$)$ after the second measurement on day 3-5, with a high level of peak compared to the second group of newborns with asphyxia and proven sepsis. The statistical analysis confirmed significantly different values of PCT in the analyzed time period in the first group of newborns with RDS and proven sepsis with mechanical ventilation (MV) and bubble continuous positive airway pressure (BCPAP) compared to the second group of newborns with asphyxia and proven sepsis, $p<0.001$. The statistical analysis confirmed significantly different values of CRP in the analyzed time period in the second group of newborns with asphyxia and proven sepsis with MV and BCPAP, $\mathrm{p}<0.001$, compared to the first group of newborns with RDS and proven sepsis.

\section{Conclusion}

In critically ill newborns admitted to the ICU and who are on invasive respiratory support, rapid identification and treatment of the septic condition has a major impact on clinical course, management, and outcome. Our study found that PCT values in the analyzed period were higher in newborns with RDSy on invasive respiratory support, compared to newborns with asphyxia on respiratory support. CRP values in the analyzed period were higher in newborns with proven sepsis and asphyxia and those who were on invasive respiratory support, compared to newborns with proven sepsis and RDSy who were on respiratory support. PCT as an early predictive marker can be used in newborns with a clinical picture of sepsis and with RDSy who are on respiratory support. CRP measurement is of significant clinical significance in newborns with asphyxia and clinical picture of sepsis who are on respiratory support.

\section{References}

1. Kliegman RM, Stanton B, Geme JS, St Schor NF, Behrman RE. Nelson textbook of pediatrics. 20th ed. Philadelphia (PA): Elsevier Health Sciences; 2015

2. Whicher J, Bienvenu J, Monneret G. Procalcitonin as an acute phase marker. Ann Clin Biochem 2001;38(Pt 5):483-493.

3. Gogos CA, Drosou E, Bassaris HP, Skoutelis A. Pro- versus anti-inflammatory cytokine profile in patients with severe sepsis: a marker for prognosis and future therapeutic options. J Infect Dis 2000;181:176180.

4. Müller B, White JC, Nylén ES, Snider RH, Becker KL, Habener JF. Ubiquitous expression of the calcitonin-i gene in multiple tissues in response to sepsis. J Clin Endocrinol Metab 2001;86:396-404.

5. Chiesa C, Panero A, Rossi N, Stegagno M, De Giusti M, Osborn JF, et al. Reliability of procalcitonin concentrations for the diagnosis of sepsis in critically ill neonates. Clin Infect Dis 1998;26:664-672.

6. Christ-Crain M, Müller B. Procalcitonin in bacterial infections: hype, hope, more or less? Swiss Med Wkly 2005;135:451-460.

7. Uzzan B, Cohen R, Nicolas P, Cucherat M, Perret GY. Procalcitonin as a diagnostic test for sepsis in criti- 
cally ill adults and after surgery or trauma: a systematic review and meta-analysis. Crit Care Med 2006;34:1996-2003.

8. Bouiller JP, Dreyfus M, Mortamet G, Guillois B, Benoist G. Intrapartum asphyxia: Risk factors and shortterm consequences. Journal de gynecologie, obstetrique et biologie de la reproduction 2015;45(6):626-32.

9. Mehrabadi A, Lisonkova S, Joseph KS. Heterogeneity of respiratory distress syndrome: risk factors and morbidity associated with early and late gestation disease. BMC pregnancy and childbirth 2016;16(1):281.

10. Reuter S, Moser C, Baack M. Respiratory distress in the newborn. Pediatrics in review. 2014;35(10):417.

11. Hibbard JU, Wilkins I, Sun L, Gregory K, Haberman S, Hoffman M et al. Respiratory morbidity in late preterm births. JAMA: the journal of the American Medical Association 2010;304(4):419.

12. Bak SY, Shin YH, Jeon JH, Park KH, Kang JH, Cha DH, et al. Prognostic factors for treatment outcomes in transient tachypnea of the newborn. Pediatrics International 2012;54(6):875-80.

13. Bohlin K, Gudmundsdottir T, KatzSalamon M, Jonsson B, Blennow M. Implementation of surfactant treatment during continuous positive airway pressure. Journal of Perinatology 2007;27(7):422-7.

14. Aldana-Aguirre JC, Pinto M, Featherstone RM, Kumar M. Less invasive surfactant administration versus intubation for surfactant delivery in preterm infants with respiratory distress syndrome: a systematic review and meta-analysis. Archives of
Disease in Childhood-Fetal and Neonatal Edition 2017;102(1):F17-23.

15. Bancalari E, Claure N. Advances in respiratory support for high risk newborn infants. Maternal health, neonatology and perinatology 2015;1(1):1-0.

16. Aly H, Mohamed MA. An experience with a bubble CPAP bundle: is chronic lung disease preventable?. Pediatric research 2020;88(3):44450.

17. Baier C, Pirr S, Ziesing S, Ebadi E, Hansen G, Bohnhorst B, Bange FC. Prospective surveillance of bacterial colonization and primary sepsis: findings of a tertiary neonatal intensive and intermediate care unit. Journal of Hospital Infection 2019;102(3):325-31.

18. Ugarte H, Silva E, Mercan D, DeMendonca A, Vincent JL. Procalcitonin used as a marker of infection in the intensive care unit. Crit Care Med 1999;27:498-504.

19. Remington JS, Klein JO. Bacterial sepsis and meningitis. Infectious diseases of the fetus and newborn infant. Philadelphia: W.B.Saunders Company; 2001.

20. Singer M, Deutschman CS, Seymour CW, Shankar-Hari M, Annane D, Bauer $\mathrm{M}$ et al. The third international consensus definitions for sepsis and septic shock (Sepsis-3). JAMA 2016;315(8):801-10.

21. Stoll BJ, Hansen N, Fanaroff AA, et al. Changes in pathogens causing early-onset sepsis in very-low-birthweight infants. N Engl J Med 2002; 347(4): 240-247.

22. Weinschenk NP, Farina A, Bianchi DW. Premature infants respond to early-onset and late onset sepsis 
with leukocyte activation. J Pediatr 2000;137:345-350.

23. Hermansen CL and Lorah KN. Respiratory distress in the newborn. Am Fam Physician 2007;76(7):987-94

24. Stoll BJ, Hansen N, Fanaroff AA, et al. Changes in pathogens causing early-onset sepsis in very-low-birthweight infants. N Engl J Med 2002; 347(4):240-247.

25. Whicher J, Bienvenu J, Monneret G. Procalcitonin as an acute phase marker. Ann ClinBiochem 2001;38(Pt 5):483-493.

26. Oswyn G, Vince JD, Friesen H. Perinatal asphyxia at Port Moresby General Hospital: a study of incidence, risk factors and outcome. P N G Med J 2000;43:110-120. 4.

27. PálsdóttirK, Thórkelsson T, Hardardóttir H, DagbjartssonA. Birth asphyxia, neonatal risk factors for hypoxic ischemic encephalopathy. Laeknabladid 2007; 93(10): 669-73

28. Riedel S, et al. Procalcitonin as a marker for the detection of bacteremia and sepsis in the emergency department. Am J ClinPathol 2011; 135: 182-89.

29. Schuetz P, Christ-Crain M, Müller B. Procalcitonin and other biomarkers for the assessment of disease severity and guidance of treatment in bacterial infections. Adv Sepsis 2008; 6,3: 82-89.

30. Rhodes A, Evans LE, Alhazzani W, et al. Surviving Sepsis Campaign: International Guidelines for Management of Sepsis and Septic Shock: 2016. Intensive Care Med 2017; 43(3): 304-77. 